\title{
Penggunaan Kulit Nanas Fermentasi dalam Ransum yang Mengandung Gulma Berkhasiat Obat terhadap Organ Pencernaan Ayam Broiler
}

\author{
Use of Fermented Pineapple Peel in the Ration Containing Medicinal Weeds on Innert Organs \\ of Broiler Chicken)
}

\author{
W. Ibrahim ${ }^{*}$, R. Mutia ${ }^{2}$, dan Nurhayati $^{3}$ \\ ${ }^{1}$ Program Studi Peternakan, Fakultas Pertanian Universitas Musi Rawas \\ ${ }^{2}$ Departemen Ilmu Nutrisi dan Teknologi Pakan, Fakultas Peternakan IPB \\ ${ }^{3}$ Fakultas Peternakan, Universitas Jambi \\ *E-mail: ib.ib48@yahoo.co.id
}

\begin{abstract}
The aim of this study was to determine the effect of using fermented pineapple peel in the ration containing medicinal weeds on inert organs of broiler chicken. Two hundreds 2 days male broiler chicken Cob strain were used in this study and kept for 42 days. The experiment was designed into completely randomized design (CRD) with 5 treatments and 5 replicates. Treatments consisted of $\mathrm{P} 0=0 \%$ of fermented pineapple peels meal (FPPM) in ration containing $0 \%$ medicinal weed (MW), positive control). $\mathrm{P} 1=0 \%$ of fermented pineapple peels meal (FPPM) in the ration containing $2 \%$ medicinal weed (MW), negative control). P2 $=7.5 \%$ of FPPM in the ration containing $2 \%$ medicinal weed $(\mathrm{MW}) . \mathrm{P} 3=15 \%$ of FPPM in the ration containing $2 \%$ medicinal weed $(\mathrm{MW}) . \mathrm{P} 4=22,5 \%$ of FPPM in the ration containing $2 \%$ medicinal weed (MW). The parameters were innert organs, volume of bile and $\mathrm{pH}$ of intestine. The observed data were analyzed by statistical product and service solution (SPSS 16.0) and significant effect among treatments were tested by Duncan's multiple range test. Results showed that use of fermented pineapple peel meel up to $22.5 \%$ with addition medicinal weeds was the not affect on innert organs of broiler chicken.
\end{abstract}

Key words: broiler, fermentation, pineapple peel meal

\begin{abstract}
ABSTRAK
Penelitian ini bertujuan untuk mengetahui penanganan kulit nanas fermentasi dalam ransum yang mengandung gulma berkhasiat obat terhadap organ pencernaan ayam broiler. Penelitian ini menggunakan DOC jantan strain cob umur 2 hari sebanyak 200 ekor yang dipelihara selama 42 hari. Penelitian ini menggunakan Rancangan Acak Lengkap (RAL) dengan 5 perlakuan dan 5 ulangan $\mathrm{P} 0=0 \%$ tepung kulit nanas fermentasi (TKNF) dalam ransum mengandung $0 \%$ gulma obat(GO), (kontrol positif), $\mathrm{P} 1=0 \%$ tepung kulit nanas fermentasi (TKNF) dalam ransum mengandung $2 \%$ gulma obat (GO),( kontrol negatif), P2 $=7.5 \%$ tepung kulit nanas fermentasi dalam ransum mengandung $2 \%$ gulma berkhasiat obat, P3 $=15 \%$ tepung kulit nanas fermentasi dalam ransum mengandung $2 \%$ gulma berkhasiat obat, $\mathrm{P} 4=22.5 \%$ tepung kulit nanas fermentasi dalam ransum mengandung $2 \%$ gulma berkhasiat obat. Parameter yang diamati meliputi organ pencernaan. Pengaruh yang nyata terhadap parameter dianalisa dengan uji jarak berganda Duncan. Data yang diperoleh dari setiap parameter dianalisis ragam (ANOVA) menggunakan bantuan software SPSS 16.0. Dari hasil penelitian disimpulkan bahwa penggunaan kulit nanas fermentasi dapat digunakan sampai taraf $22.5 \%$ dalam ransum yang mengandung gulma berkhasiat obat tidak mempengaruhi organ pencernaan ayam broiler.
\end{abstract}

Kata kunci : broiler, fermentasi, tepung kulit nanas

\section{PENDAHULUAN}

Produksi buah nanas secara nasional pada tahun 2013 adalah sebesar 1.558.196 ton setahun (Badan Pusat Statistik Indonesia,
2013). Begitu pula untuk daerah Jambi pada tahun yang sama yang produksinya mencapai 144.896 ton (Badan Pusat Statistik Provinsi Jambi, 2013). Menurut Nurhayati (2013) limbah kulit nanas yang dihasilkan dari 
industri pengolahan buah nanas di Provinsi Jambi mencapai 135 ribu ton setahun. Ini berarti bahwa potensi kulit nanas sebagai sumber pakan ternak cukup tinggi serta cukup menjanjikan. Menurut Raharjo et al. (2013) terdapat sekitar 596 ribu ton setahun limbah kulit nanas yang dapat dimanfaatkan sebagai bahan pakan ternak alternatif. Produksi limbah pengolahan nanas sekitar 75-85\% yaitu terdiri dari kulit, mahkota dan inti, dimana untuk kulitnya saja sekitar 30-35\% (Lubis, 1991). Kulit nanas merupakan sisa pengolahan buah nanas setelah diambil bagian dalamnya yang jumlahnya bisa mencapai $27 \%$ dari total produksi buah nanas (Nurhayati 2013). Nurhayati (2013) mendapatkan bahwa tepung kulit nanas masih memiliki nilai gizi yang baik yaitu bahan kering 88,9503\%, abu 3,8257\%, serat kasar 27,0911\%, protein kasar 8,7809\% dan lemak kasar 1,1544\%. Selain itu kulit nanas juga mengandung gula reduksi sebanyak $13,65 \%$.

Gula reduksi adalah gula yang mempunyai kemampuan untuk mereduksi akibat adanya senyawa hidroksi yang bebas dan reaktif (Lehninger 1982). Contoh gula reduksi adalah glukosa dan fruktosa. Tingginya gula reduksi pada kulit nanas dapat dijadikan sumber energi pada unggas. Akan tetapi penggunaan kulit nanas dalam ransum unggas dibatasi oleh tingginya kandungan serat kasar yang tinggi $(19,69 \%)$ dan protein kasar yang rendah (3.50\%), Serat kasar yang tinggi mengakibatkan zat makanan sulit dicerna oleh ternak unggas sehingga dapat menurunkan kecernaan zat-zat makanan, maka hal terbaik yang harus dilakuakn yaitu dengan cara fermentasi.
Menurut Sears dan Sears (1999) yoghurt adalah salah satu produk fermentasi, yoghurt didefinisikan sebagai produk pangan berasal dari susu sapi dengan bentuk seperti bubur atau es krim, yang merupakan hasil fermentasi susu dengan bakteri Lactobacillus bulgaricus dan Streptococcus thermophillus. Menurut Winarno (1997) fermentasi merupakan perubahan sifat bahan pangan sebagai akibat pemecahan kandungan bahan tersebut, perubahan tersebut bisa berupa $\mathrm{pH}$, kelembaban, aroma dan perubahan nilai gizi.

Selain penggunaan yoghurt sebagai sumber bakteri, penambahan gulma berkhasiat obat sebagai feed aditif alami dalam ransum juga dilakukan untuk menjaga kesehatan ternak. Gulma berkhasiat obat seperti rumput mutiara (Hedyotis corymbosa atau Oldenlandia corymbosa L), sidaguri (Sida cordifolia), bandotan (Ageratum conyzoides L) dan patikan kebo (Euphorbia hirta L.) mengandung beberapa senyawa bioaktif seperti minyak atsiri, asam oleonat, Bsitosterol, sitisterol, D-glukosida, asam ursolat, p-asam kumarat, flavonoid, tannin dan kumarin (Djauhariya dan Hernani, 2004). Penelitian ini bertujuan untuk mengetahui penggnaan kulit nanas fermentasi dalam ransum yang mengandung gulma berkhasiat obat terhadap organ pencernaan ayam broiler.

\section{MATERI DAN METODE}

Alat yang digunakan antara lain timbangan, mesin pengiling, DOC jantan umur 2 hari sebanyak 200 ekor. Kandang yang digunakan pada penelitian ini adalah kandang berukuran $80 \mathrm{~cm}$ x $80 \mathrm{~cm}$ x $100 \mathrm{~cm}$ sebanyak 25 petak, setiap petak kandang dilengkapi dengan tempat makan dan tempat minum serta 
bola lampu listrik 25 watt sebagai pemanas, dan litter (serbuk gergaji) sebagai alas kandang dan timbangan

Pakan yang digunakan dalam penelitian ini adalah: kulit nanas yang difermentasi dengan yoghurt sebanyak $3 \mathrm{ml} / \mathrm{kg}$ selama 24 jam, ransum komersil, jagung, dedak halus, tepung ikan dan bungkil kedele. Bahan aditif yang digunakan berasal dari kombinasi gulma berkhasiat obat yaitu rumput mutiara: sidaguri: bandotan : patikan kebo dengan perbandingan $1: 2: 2: 2$. Ransum disusun isoprotein dan isoenergi. Pakan dan air minum diberikan secara ad libitum. Komposisi dan kandungan zat makanan ransum yang dapat dilihat pada Tabel 1.

Tabel 1 Komposisi dan kandungan zat makanan ransum perlakuan

\begin{tabular}{lccccc}
\hline \multirow{2}{*}{ Bahan Pakan } & \multicolumn{5}{c}{ Perlakuan } \\
\cline { 2 - 6 } & P0 & P1 & P2 & P3 & P4 \\
\hline Ransum komersil BR I & 50 & 50 & 50 & 50 & 50 \\
Jagung & 15 & 15 & 13 & 5 & 5 \\
Dedak & 20 & 18 & 12.5 & 13 & 5.5 \\
Bungkil kedele & 7 & 7 & 7 & 7 & 7 \\
Tepung Ikan & 8 & 8 & 8 & 8 & 8 \\
Kulit nanas fermentasi & 0 & 0 & 7.5 & 15 & 22.5 \\
Gulma obat & 0 & 2 & 2 & 2 & 2 \\
Jumlah (\%) & 100 & 100 & 100 & 100 & 100 \\
\hline Zat makanan \%* & & & & & \\
\hline Bahan kering & 89.20 & 87.46 & 86.92 & 86.31 & 85.79 \\
Bahan organik & 91.51 & 89.77 & 88.98 & 87.54 & 86.96 \\
Protein kasar & 21.54 & 21.32 & 21.38 & 21.66 & 21.65 \\
Lemak kasar & 6.36 & 6.21 & 5.79 & 5.67 & 5.15 \\
Serat kasar & 5.15 & 4.88 & 5.30 & 6.47 & 6.65 \\
Kalsium & 0.74 & 0.74 & 0.72 & 0.72 & 0.70 \\
Fospor & 0.59 & 0.58 & 0.57 & 0.55 & 0.54 \\
Energy metabolisme & 3124 & 3074 & 3148 & 3172 & 3263 \\
(kkal/kg) & & & & & \\
\hline
\end{tabular}

Penelitian ini menggunakan Rancangan Acak Lengkap (RAL) dengan 5 perlakuan dan 5 ulangan :

$\mathrm{P} 0=0 \%$ tepung kulit nanas fermentasi (TKNF) dalam ransum mengandung $0 \%$ gulma obat (GO), (kontrol positif)

$\mathrm{P} 1=0 \%$ tepung kulit nanas fermentasi (TKNF) dalam ransum mengandung $2 \%$ gulma obat (GO), (kontrol negatif).

$\mathrm{P} 2=7.5 \%$ tepung kulit nanas fermentasi dalam ransum mengandung $2 \%$ gulma berkhasiat obat.
P3 $=15 \%$ tepung kulit nanas fermentasi dalam ransum mengandung $2 \%$ gulma berkhasiat obat.

$\mathrm{P} 4=22.5 \%$ tepung kulit nanas fermentasi dalam ransum mengandung $2 \%$ gulma berkhasiat obat.

Data yang diperoleh dari setiap parameter dianalisis ragam (ANOVA) menggunakan bantuan software SPSS 16.0. Pengaruh perlakuan yang nyata terhadap parameter yang diamati dilanjutkan dengan Uji 
Jarak Berganda Duncan (Steel dan Torrie, 1989).

\section{HASIL DAN PEMBAHASAN}

\section{Pengaruh Perlakuan Terhadap Pankreas}

Analisis ragam menunjukkan penggunaan tepung kulit nanas fermentasi yoghurt berpengaruh nyata $(\mathrm{P}<0.05)$ terhadap bobot relative pankreas ayam broiler selama penelitian (Tabel 2). Pankreas berfungsi sebagai tempat penting dalam pencernaan zatzat makanan, dimana pankreas tersebut menghasilkan getah pankreas yang mengandung amilolitik, lipolitik dan proteolitik yang dapat menghidrolisis pati, lemak serta protein. Buah nanas mengandung enzim bromelin, (enzim protease yang dapat menghidrolisa protein, protease atau peptida). Bobot pancreas berkisar antara $0.22-0.28 \%$ lebih rendah dibandingkan dengan hasil penelitian Djunaidi et al. (2009) yang mendapatkan hasil $0.24-0.29 \%$ ketika ayam yang diberi pakan limbah udang hasil fermentasi Bacillus sp.

Tabel 2. Bobot potong, pankreas, volume empedu dan organ pencernaan setiap perlakuan

\begin{tabular}{lccccc}
\hline \multicolumn{1}{c}{ Peubah } & \multicolumn{5}{c}{ Perlakuan } \\
\cline { 2 - 6 } & $\mathrm{P} 0$ & $\mathrm{P} 1$ & $\mathrm{P} 2$ & $\mathrm{P} 3$ & $\mathrm{P} 4$ \\
\hline $\begin{array}{l}\text { Pancreas (\%) } \\
\text { Volume }\end{array}$ & $0.23 \pm 0.42 \mathrm{~b}$ & $0.22 \pm 0.03 \mathrm{~b}$ & $0.25 \pm 0.02 \mathrm{ab}$ & $0.26 \pm 0.04 \mathrm{ab}$ & $0.28 \pm 0.04 \mathrm{a}$ \\
empedu (m1/g) & $6 \times 10^{-4} \pm 0.02 \mathrm{~b}$ & $7 \times 10^{-4} \pm 0.02 \mathrm{ab}$ & $10 \times 10^{-4} \pm 0.03 \mathrm{ab}$ & $7 \times 10^{-4} \pm 0.05 \mathrm{ab}$ & $11 \times 10^{-4} \pm 0.06 \mathrm{a}$ \\
Provetrikulus & $0.54 \pm 0.11$ & $0.52 \pm 0.22$ & $0.54 \pm 0.25$ & $0.53 \pm 0.20$ & $0.49 \pm 0.21$ \\
$(\%)$ & $1.32 \pm 0.14$ & $1.48 \pm 0.06$ & $1.55 \pm 0.10$ & $1.59 \pm 0.10$ & $1.57 \pm 0.07$ \\
Ventrikulus(\%) & & & & \\
Jantung (\%) & $0.41 \pm 0.06$ & $0.48 \pm 0.06$ & $0.48 \pm 0.76$ & $0.47 \pm 0.81$ & $0.46 \pm 0.11$ \\
Limpa(\%) & $0.21 \pm 0.12$ & $0.21 \pm 0.16$ & $0.16 \pm 0.13$ & $0.18 \pm 0.06$ & $0.18 \pm 0.09$ \\
Hati (\%) & $2.49 \pm 0.48$ & $2.37 \pm 0.40$ & $2.23 \pm 0.33$ & $2.24 \pm 0.24$ & $2.28 \pm 0.52$ \\
\hline
\end{tabular}

Huruf yang berbeda pada baris yang sama menunjukkan perbedaan nyata $(\mathrm{P}<0.05)$

Pengaruh Perlakuan Terhadap Volume Empedu

Analisis ragam menunjukkan penggunaan tepung kulit nanas fermentasi yoghurt berpengaruh nyata $(\mathrm{P}<0.05)$ terhadap volume empedu (Tabel 2). Hal ini menunjukkan adanya pemberian kulit nanas fermentasi yoghurt dalam ransum mempengaruhi kerja organ pencernaan termasuk empedu yang merupakan tempat akumulasi cairan lemak dan kolesterol. Monsoub et al (2011) melaporkan bakteri $L$. acidophilus mampu mendekonjugasi asam glikokolat dan taurokolat dalam kondisi anaerob. Dekonjukasi yang terjadi pada asam empedu dapat meningkatkan kelarutan kolesterol dan mempengaruhi kolesterol serum sehingga membantu penyerapan kolesterol dari usus. Candra (2014) menyatakan cairan empedu merupakan cairan garam berwarna kuning kehijauan yang mengandung kolesterol, fosfolipid, lesitin serta pigmen empedu.

\section{Pengaruh Perlakuan Terhadap} Proventrikulus

Analisis ragam menunjukkan penggunaan tepung kulit nanas fermentasi yoghurt dalam ransum tidak berpengaruh 
nyata $(\mathrm{P}>0.05)$ terhadap bobot proventrikulus (Tabel 2) Proventrikulus berkisar antara 0.49 $0.54 \%$ lebih tinggi dibandingakn dengan penelitian Moreno et al. (2009) yang mendapatkan bobot proventrikulus berkisar $0.74-0.82 \%$ ketika ayam yang diberi pakan berserat. Akan tetapi lebih rendah dengan penelitian Jimenez et al. (2009) yang mendapatkan hasil bobot proventrikulus berkisar $0.40-0.44 \%$ ketika ayam diberi pakan berserat

\section{Pengaruh Perlakuan Terhadap Ventrikulus} Analisis ragam menunjukkan penggunaan tepung kulit nanas fermentasi yoghurt dalam ransum tidak berpengaruh nyata $(\mathrm{P}>0.05)$ terhadap bobot ventrikulus (Tabel 2). Tidak berpengaruhnya diduga sulitnya ventrikulus dalam mencerna tepung kulit nanas fermentasi yang ada dalam ransum. Menurut Nort and Bell (1990) menyatakan bahwa ventrikulus bekerja memecah dan mengiling pakan menjadi partikel yang lebih kecil terutama pakan yang mengandung serat, ventikulus terletak diantara tembolok dan batas teratas bagian otot yang kuat dan dapat menghasilkan kekuatan yang besar dan juga terdapat mukosa. Dalam penelitian ini berat ventrikulus berkisar 1.32-1.59\%

\section{Pengaruh Perlakuan Terhadap Jantung}

Analisis ragam menunjukkan penggunaan tepung kulit nanas fermentasi yoghurt dalam ransum tidak berpengaruh nyata $(\mathrm{P}>0.05)$ terhadap bobot jantung (Tabel 2). Pada saat pengamatan Jantung masih dalam keadaan normal setelah diberikan pakan dengan menggunakan tepung kulit nanas fermentasi dalam ransum. Bobot Jantung dalam penelitian ini berkisar antara 0.41$0.48 \%$.

\section{Pengaruh Perlakuan Terhadap Limpa}

Analisis ragam menunjukkan penggunaan tepung kulit nanas fermentasi yoghurt dalam ransum tidak berpengaruh nyata $(\mathrm{P}>0.05)$ terhadap bobot limpa (Tabel 2). Dalam penelitian ini berat limpa berkisar antara $0.16-0.21 \%$. Lebih tinggi dari hasil yang didapatkan Hermana et al. (2008) yang mendapatkan bobot limpa berkisar antara 0.09 - $0.19 \%$ ketika ayam diberi pakan tepung daun salam.

\section{Pengaruh Perlakuan Terhadap Hati}

Analisis ragam menunjukkan penggunaan tepung kulit nanas fermentasi yoghurt dalam ransum tidak berpengaruh nyata $(\mathrm{P}>0.05)$ terhadap bobot hati (Tabel 2). Bobot hati berkisar antara 2,23\%-2,49\%. Menurut Putnam (1991) persentase hati berkisar antara 1,70\%-2,80\%. Akmal (2008) menyatakan bobot hati berkisar 1,93\%-2,18\% ketika ayam diberikan tepung daun sengon.

\section{Pengaruh Perlakuan Terhadap Usus Halus dan Usus Besar}

Analisis ragam menunjukkan penggunaan tepung kulit nanas fermentasi yoghurt berpengaruh nyata $(\mathrm{P}<0.05)$ terhadap terhadap bobot usus halus yeyenum (Tabel 3). Bobot yeyenum berkisar antara $0.81-1.10 \%$ lebih rendah dengan hasil penelitian Djunaidi et al. (2009) mendapatkan hasil bobot yeyenum berkisar $1.30-2.60 \%$ ketika pakan diberi limbah udang fermentasi Bacillus sp. Berpengaruhnya bobot yeyenum dikerenakan penggunaan tepung kulit nanas fermentasi 
dapat meningkatkan kerja jejenum ayam Pakan fermentasi menyebabkan saluran broiler dalam mengekresikan enzim gastroinstinal lebih sehat. Satu studi pencernaan seperti selullase dan hemiselullase. menunjukkan bahwa pakan fermentasi harus Hal ini diduga karena dengan penambahan disebut "Fermbiotics" karena memberikan yoghurt sebagai probiotik pada tepung kulit manfaat yang sama seperti probiotik dalam nanas memungkinkan dapat meningkatkan makanan manusia (Niba et. al., 2009). Temuan pertumbuhan mikroorganisme dalam yeyenum ini sepakat dengan yang dilaporkan oleh ayam broiler, dengan banyaknya Chaing et. al. (2010); Uchewa dan Onu (2012) mikroorganisme yang menguntungkan dalam dan Firman et. al. (2013) bahwa pakan yeyenum maka penyerapan zat-zat makanan fermentasi menyebabkan saluran gastroinstinal yang terkandung dalam pakan lebih efisien. lebih sehat.

Tabel 3. Bobot usus halus, bobot usus besar, panjang usus halus dan $\mathrm{pH}$ usus halus setiap perlakuan.

\begin{tabular}{|c|c|c|c|c|c|}
\hline \multirow[t]{2}{*}{ Peubah } & \multicolumn{5}{|c|}{ Perlakuan } \\
\hline & P0 & P1 & $\mathrm{P} 2$ & P3 & P4 \\
\hline \multicolumn{6}{|l|}{ Bobot usus halus } \\
\hline Duodenum(\%) & $0.55 \pm 0.15$ & $0.57 \pm 0.15$ & $0.51 \pm 0.08$ & $0.53 \pm 0.08$ & $0.58 \pm 0.12$ \\
\hline Yeyenum(\%) & $0.99 \pm 0.22 \mathrm{ab}$ & $1.10 \pm 0.19 \mathrm{a}$ & $0.88 \pm 0.21 \mathrm{ab}$ & $0.86 \pm 0.19 \mathrm{ab}$ & $0.81 \pm 0.22 b$ \\
\hline $\operatorname{Ileum}(\%)$ & $0.83 \pm 0.21$ & $0.98 \pm 0.17$ & $0.77 \pm 0.10$ & $0.83 \pm 0.21$ & $0.75 \pm 0.24$ \\
\hline \multicolumn{6}{|l|}{ Bobot usus besar } \\
\hline $\mathrm{Caeca}(\%)$ & $0.66 \pm 0.21$ & $0.59 \pm 0.21$ & $0.68 \pm 0.21$ & $0.66 \pm 0.16$ & $0.62 \pm 0.12$ \\
\hline Colon(\%) & $0.31 \pm 0.04$ & $0.24 \pm 0.03$ & $0.25 \pm 0.03$ & $0.28 \pm 0.05$ & $0.22 \pm 0.26$ \\
\hline \multicolumn{6}{|c|}{ Panjang Usus Halus } \\
\hline Duodenum(cm) & $18.0 \pm 0.25$ & $19.0 \pm 0.54$ & $17.0 \pm 0.20$ & $19.0 \pm 0.25$ & $19.0 \pm 0.22$ \\
\hline Yeyenum(cm) & $43.0 \pm 1.33$ & $40.0 \pm 0.39$ & $41.0 \pm 0.59$ & $44.0 \pm 0.71$ & $47.0 \pm 0.48$ \\
\hline Iluem $(\mathrm{cm})$ & $47.0 \pm 0.91$ & $43.0 \pm 0.57$ & $43.0 \pm 0.55$ & $47.0 \pm 0.71$ & $47.0 \pm 1.15$ \\
\hline \multicolumn{6}{|l|}{ pH usus halus } \\
\hline Duodenum & $5.3 \pm 0.83$ & $5.4 \pm 0.51$ & $5.3 \pm 0.48$ & $5.3 \pm 0.48$ & $5.4 \pm 0.51$ \\
\hline Yeyenum & $5.8 \pm 0.42$ & $5.3 \pm 0.48$ & $5.4 \pm 0.51$ & $5.2 \pm 0.42$ & $5.3 \pm 0.48$ \\
\hline Ileum & $5.2 \pm 0.42$ & $5.2 \pm 0.42$ & $5.4 \pm 0.51$ & $5.6 \pm 0.51$ & $5.4 \pm 0.51$ \\
\hline
\end{tabular}

Huruf yang berbeda pada baris yang sama menunjukkan perbedaan nyata $(\mathrm{P}<0.05)$

Hasil analisis ragam menunjukkan penggunaan tepung kulit nanas fermentasi yoghurt dalam ransum tidak berpengaruh nyata $(\mathrm{P}>0.05)$ terhadap bobot usus halus (duodenum, ileum) (Tabel 3). Bobot duodenum pada penelitian ini berkisar antara $0.51-0.58 \%$. Lebih tinggi dari hasil penelitian Svihus et al. (2010) mendapatkan hasil bobot duodenum berkisar anatara 0.3 $0.5 \%$. Akan tetapi lebih rendah dengan hasil penelitian Djunaidi et al. (2009) yang mendapatkan hasil $0.81-0.96 \%$ ketika ayam diberi pakan limbah udang fermentasi Bacillus sp. Begitupun dengan bobot ileum (Tabel 3). Berkisar anatara $0.75-0.98 \%$ lebih rendah dengan hasil penelitian Djunaidi et al. (2009) ketika ayam diberikan pakan limbah udang fermentasi bacillus sp.

Hasil analisis ragam menunjukkan penggunaan tepung kulit nanas fermentasi yoghurt dalam ransum tidak berpengaruh nyata $(\mathrm{P}>0.05)$ terhadap Bobot usus besar 
(caeca, colon), (Tabel 3). Menunjukkan Bobot caeca bekisar $0.59-0.68 \%$ lebih tinggi dengan hasil penelitian Moreno et al. (2009) yang mendapatkan bobot caeca berkisar 0.48 $0.55 \%$. Sedangkan berat colon (Tabel 3). Berkisar antara $0.22-0.31 \%$, lebih rendah dibandingkan dengan hasil penelitian Mosami. (2011) yang mendapatkan hasil bobot colon sebesar $0.13-0.16 \%$.

Hasil analisis ragam menunjukkan penggunaan tepung kulit nanas fermentasi yoghurt dalam ransum tidak berpengaruh nyata $(\mathrm{P}>0.05)$ terhadap panjang usus halus (duodenum, yeyenum, ileum) (Tabel 3). Hasil antar perlakuan yang relatif sama diduga karena pakan antar perlakuan telah mengalami proses pencernaan dan penyerapan yang dilakukan diusus halus terutama yeyenum sehingga tidak berpengaruh nyata terhadap bobot usus halus dan usus besar serta panjang usus halus dan usus besar kecuali pada bobot usus halus jejenum. Memungkinkan juga bobot relative sama dikarenakan enzim pencernaan tidak bekerja maksimal pada parameter. (Tabel 3) Menunjukkan panjang usus halus duodenum berkisar antara 17- 19 cm lebih rendah dibandingkan dengan hasil penelitian Mosami (2011) yang mendapatkan hasil panjang $29-31 \mathrm{~cm}$, sedangkan panjang jejunum pada penelitian ini berkisar antara 40 - $47 \mathrm{~cm}$ lebih rendah dengan hasil penelitian Mosami (2011) yang mendapatkan hasil berkisar antara $63-73 \mathrm{~cm}$. Ileum pada penelitian ini berkisar antara $43-47 \mathrm{~cm}$. lebih rendah dari hasil Mosami (2011) yang mendapatkan hasil $63-76 \mathrm{~cm}$.

\section{Pengaruh Perlakuan Terhadap pH Usus Halus}

Analisis ragam menunjukkan penggunaan tepung kulit nanas fermentasi yoghurt dalam ransum tidak berpengaruh nyata $(\mathrm{P}>0.05)$ terhadap $\mathrm{pH}$ usus halus (Duodenum, Jejenum, Ileum). Menunjukkan bahwa $\mathrm{pH}$ memberikan hasil yang baik yaitu memiliki rata-rata 5.3 menurut Akhardianto (2010) menyatakan bahwa bakteri saluran pencernaan membutuhkan $\mathrm{pH}$ sekitar 5.0 untuk berkembang biak.

\section{KESIMPULAN}

Dari hasil penelitian disimpulkan bahwa penggunaan kulit nanas fermentasi dapat digunakan sampai taraf $22.5 \%$ dalam ransum yang mengandung gulma berkhasiat obat tidak mempengaruhi organ pencernaan ayam broiler.

\section{DAFTAR PUSTAKA}

Akhardianto S. 2010. Pengaruh pemberian probiotik, temban, biovet dan biolacta terhadap persentase karkas, bobot lemak abdomen dan organ dalam ayam broiler. Jurnal sains dan teknologi Indonesia. 12 (1) : 53 - 59.

Akmal. 2008. Pengaruh pemberian daun sengon (Albizzia falcataria) hasil rendaman dengan larutan $\mathrm{Ca}(\mathrm{OH})_{2}$ terhadap bobot karkas dan bobot organ pencernaan ayam pedaging . Jurnal ilmu-ilmu peternakan. 11 (4) : 100- 107.

Badan Pusat Statistik Provinsi Jambi. 2013. Jambi dalam Angka 2013. BPS Provinsi Jambi, Jambi.

Badan Pusat Statistik. 2013. Produksi buahbuahan dan sayuran tahunan di indonesia, 1995 - 2013. Badan Pusat Statistik, Jakarta. 
http://www.bps.go.id/tab_sub/view.php ?kat $=3 \&$ tabel $=1 \&$ daftar $=1 \&$ id_subye $\mathrm{k}=55 \&$ notab $=15$.

Candra, A. A. 2014. Improvement of broiler production performance with addition turmeneric extraction solvent ethanol. Jurnal penelitian pertanian terapan. 14 (1): 64-69.

Chiang, G., W. Q. Lu, X. S. Piao, J. K. Hu, L. M. Gong, and P. A. Thacker. 2010. Effects of feeding solid-state fermented rapeseed meal on performance, nutrient digestibility, intestinal ecology and intestinal morphology of broiler chickens. Asian-Aust. J. Anim. Sci. 23(2): 263-271.

Djunaidi, I. H. Y., T. Yuwanta, Supadomo, dan M. Nurcahyono. 2009. Performa dan bobot organ pencernaan ayam broiler yang diberi pakan limbah udang hasil fermentasi Bacillus sp. Media Peternakan. 32 (3) : 212-219.

Djauharia, E., dan Hernani. 2004. Gulma berkhasiat obat. Seri Agrisehat. Penebar Swadaya, Jakarta.

Firman, J. D, More and Mclntyre. 2013. Effects of dietary inclusion of a Saccharomyces cervisia fermentation product on performance and gut characteristics of male turkey to market weight. International Journal of poultry Sci. 12: 141-143.

Hermana, W., D. I. Puspitasari, K. G. Wiryawan, dan S. Saharti. 2008. Pemberian tepung daun salam (Syzygium polyanthum (wight) walp) dalam ransum sebagai bahan antibakteri Escherichia coli terhadap organ dalam ayam broiler. Media Peternakan. 31 (1) : $63-70$.

Jimenez, E., J. M. Gonzales, and A. A. Coca. 2009. Effect of source of fibre on the development and $\mathrm{pH}$ of the Gastrointestinal Tract Broiler. Journal
Animal Feed Science and Technologi. 154: 93-101

Lehninger. 1982. Dasar-Dasar Biokimia. Jilid

1. Penerjemah Suhartomo, MT, Erlangga. Jakarta.

Lubis, A. D. 1991. Pemanfaatan limbah nanas sebagai pakan ternak. Majalah Peternakan Indonesia No 76.

Mansoub, N. H. 2011. Effect of probiotic bacteria utilization on serum cholesterol and triglycrides contents and performance of broiler chickens. Global Veterinaria. 5 (3): 184-186.

Moreno, B. J., A. S. Gonzalez, R. Lazaro and G. G. Mateos. 2009. Effect of dietary fiber and fat on performance and digestive traits of broiler from one twenty-one days of age. Jurnal poultry science. 88. $2562-2574$.

Mosami, A. 2011. Effect of different inclusions of oat hull on performance carcass yield and gut development in broiler chicken. Department of animal nutrition and management. Swedish university of agricultural science. Swedish.

North, M. O. and Bell. 1990. Nutrient requirements of poultry. $9^{\text {th }}$ edition. National academy press Washington D.C.

Nurhayati. 2013. Penampilan ayam pedaging yang mengkonsumsi pakan mengandung kulit nanas disuplementasi dengan yoghurt. Agripet. 13 (02) : 15-20.

Putnam, P. A. 1991. Handbook of animal science academic press. San diego.

Raharjo. 2013. Effect of ratio of wild grass concentrate on digestibilities of dry matter and organic matter by in-vitro. Jurnal ilmiah peternakan 1(3):796-803. 
Sears, W. 1999. The family nutrition book everthyng you to know about feeding your children from birth through adolescence. Litle, Brown USA.

Stell, RGD. dan J.H. torrie. 1989. Prinsip dan prosedur statistika. Diterjemahkan oleh Bambang Sumantri. Gramedia pustaka. Jakarta.

Uchewa, E. N, and P. N. Onu. 2012. The effect of feed watting and fermented feed on the performance of broiler chick. Biochemistry. 28: 433-439.
Wijana, S., Kumalaningsih, A. Setyowati, U. Efendi dan N. Hidayat. 1991. Optimalisasi penambahan tepung kulit nanas dan proses fermentasi pada pakan ternak terhadap peningkatan kualitas nutrisi. Laporan Penelitian Hibah Agricultural Research Management Project (ARMP) Departemen Pertanian Republik Indonesia. Universitas Brawijaya. Malang.

Winarno, F. G. 1997. Biofermentasi dan Biosintesa Protein. Penerbit Angkasa. Bandung. 